\title{
Edyta Żyrek-Horodyska
}

Uniwersytet Jagielloński

ORCID: 0000-0002-7276-1736

\section{„Postanowiłem się rozlać w sensie formalnym". O transgatunkowym projekcie reporterskim Marcina Kołodziejczyka}

\begin{abstract}
Streszczenie
Celem artykułu jest przedstawienie twórczości Marcina Kołodziejczyka, którą ze względu na jej ideową i stylistyczną spójność można określić mianem transgatunkowego projektu dziennikarskiego. Autorka omawia książki reportażowe, komiks reportażouy (przygotouany przez dziennikarza we uspółpracy z Marcinem Podolcem) oraz powieść, pokazując, że tak koherentny pod względem tematycznym i językowym dorobek reportera może stać się przedmiotem badań komparatystyki mediów.
\end{abstract}

Słowa kluczowe: reportaż, prowincja, Marcin Kołodziejczyk, komparatystyka mediów, komiks reportażouy.

\section{"I have decided to expand in a formal sense". On Marcin Kolodziejczyk's cross-genre reporting project}

\begin{abstract}
The aim of the article is to discuss the books written by Marcin Kołodziejczyk, which could be described as an intergeneric journalistic project. The author of the article devotes attention to the reportages, the comics reportage (prepared by the journalist in cooperation with Marcin Podolec) and the novel, arguing that in each of these books the reader could easily find similar ideas and similar language. Therefore, such project could be discussed in the field of comparative media studies.
\end{abstract}

Keywords: reportage, provence, Marcin Kołodziejczyk, comparative media studies, comics reportage.

„Tego jeszcze nie było! Dzieło, które liczni puryści reportażu pokochają nienawidzić [..." ${ }^{1}$ - ostrzega notka uydawnicza, promująca książkę Morze po kolana. Ten lakoniczny, choć sprawnie napisany blurb, wydaje się trafnie podsumowywać charakter nie tylko tej, lecz także wielu innych prac Marcina Kołodziejczyka, którego twórczość

\footnotetext{
${ }^{1}$ M. Kołodziejczyk, M. Podolec, Morze po kolana, Wielka Litera, Warszawa 2016 (cytowany fragment pochodzi z tylnej okładki tomu).
} 
ze względu na jej hybrydyczny, transgatunkowy charakter może uywołać (by posłużyć się określeniem Władysława Tatarkiewicza) prawdziwą „rozpacz semantyka”2. Oto bowiem dziennikarz, autor takich reportaży jak między innymi Dysforia, Peryferyjczyk czy B. Opowieści z planety prowincja, decyduje się wykroczyć poza obszar non-fiction, publikując w 2018 roku powieść Prymityw. Epopeja narodowa, która zaróuno pod względem stosowanego języka, jak również opisywanej problematyki, zasadniczo koresponduje z ucześniejszym dorobkiem dziennikarskim tego autora. Odejściem od klasycznej reporterskiej narracji jest także uspomniany już komiks reportażouy pt. Morze po kolana z 2016 roku, który również wydaje się próbą poszukiwania nowych form wyrazu dla bliskich piszącemu od lat tematów i zagadnień.

Przydomek „Homera polskiej prowincji”, nadany swego czasu Kołodziejczykowi przez Jacka Hugo-Badera, pozwala wyodrębnić główny obszar zainteresowań autora, koncentrującego swą uwagę wokół obszarów nie tylko geograficznie, lecz często także ekonomicznie czy kulturowo oddalonych od zazwyczaj bliżej nieokreślonego „centrum”. Problemy mieszkańców tego obszaru autor opisuje u tekstach, które Michał Nogaś określił suego czasu (powołując się na czytelników prac Kołodziejczyka) mianem „kołodziejek”. Zarówno w fikcjonalnych, jak i w niefikcjonalnych pracach reportera można dostrzec pewne poutarzalne elementy, uspółtworzące interesujący reportersko-literacki kolaż. Poszczególne książki sygnowane nazwiskiem Kołodziejczyka stają się elementami swoistego transgatunkowego projektu, którego specyfikę określił niegdyś reporter obrazową metaforą ,orkiestracji, rozpisania [historii - przyp. E.Ż.H.] na bardzo wiele instrumentów"

Biorąc pod uwagę bogaty, genologiczne zróżnicowany, a jednocześnie spójny pod względem poutarzających się $\mathrm{w}$ nim tematów i idei dorobek Kołodziejczyka, warto zastanowić się, czy jako taki może on stać się przedmiotem eksploracji dla dynamicznie rozwijającej się w ostatnich latach komparatystyki mediów. Celem tego szkicu jest sprawdzenie, czy zastosowanie analizy porównawczej w badaniu transmedialnych projektów dziennikarskich może pomóc w ujaunieniu tematycznych i formalnych zależności pomiędzy wchodzącymi w coraz silniejsze genologiczne interferencje obszarami twórczości fikcjonalnej i niefikcjonalnej.

Eua Szczęsna zauważa, że ze względu na swoistą „otwartość” badań porównawczych „comparative methodologies can be successfully put to use in the examination

2 Por. W. Tatarkiewicz, Romantyzm, czyli rozpacz semantyka, „Pamiętnik Literacki” 1971, nr 4, s. 3-21.

3 J. Hugo-Bader, Stare wina i kwasiory. „Peryferyjczyk” Marcina Kołodziejczyka to zapis dorastania $i$ wyrastania, http://wyborcza.pl/duzyformat/7,127290,22623781,stare-wina-i-kwasiory-peryferyjczyk-marcina-kolodziejczyka.html (dostęp: 16.06.2019).

${ }^{4}$ Por. M. Nogaś, O nowych patriotach polskich, czyli Marcin Kołodziejczyk w Radiu Ksiażki, http://uyborcza.pl/ksiazki/7,163351,23280061,marcin-kolodziejczyk-w-radiu-ksiazki-opowiada-dlaczego-wkroczyl.html (dostęp: 16.06.2019).

${ }_{5}^{5}$ Marcin Kołodziejczyk: ta książa w całości składa się z podsłuchanych rozmów, audycja Wybieram Dwójkę z dnia 3.04.2018, https://www.polskieradio24.pl/76/196/Artykul/2083948\%2CMarcin-Kolodziejczyk-ta-ksiazka-w-calosci-sklada-sie-z-podsluchanych-rozmou (dostęp: 16.06.2019). 
of the multi-semiotic and multi-media reality of a text [...]"6. Wydaje się, że u przypadku twórczości Kołodziejczyka - dystrybuowanej za pomocą różnych nośników (obraz, tekst reporterski, powieść) - wybór tej właśnie metody jest w pełni adekwatny. Wyrażone przez reportera w jednym z wywiadów sformułowanie: „postanowiłem się rozlać w sensie formalnym" pokazuje bowiem, że ewolucja jego twórczości zasadza się głównie na przekształceniach samego nośnika, podczas gdy bliskie mu tematy i problemy stanowią zasadniczo niezmienny (choć wyrażany u różny sposób) rdzeń jego dorobku.

\section{Reportaż w obliczu konwergencji mediów}

Hybrydyzacja gatunków dziennikarskich, której nie oparł się także reportaż, nie jest oczywiście problemem nowym, choć niewątpliwe za sprawą rewolucji cyfrowej zyskała pewien dodatkowy wymiar. Transgatunkowość reportażu, rozumiana jako włączanie w obręb gatunku elementów przynależących do innych form wypowiedzi (dziennikarskich, literackich, wizualnych etc.), sprzyja suobodnemu przepływowi tematów czy idei pomiędzy różnymi nośnikami i prowadzi do tworzenia reportażouych projektów, wykraczających poza ramy jednej publikacji. Taki typ hybrydyzacji dyskursu reportażowego wiąże się z jego obecnym funkcjonowaniem $w$ przestrzeni wielomedialnej (drukowanej, audiowizualnej, cyfrowej), na styku zróżnicowanych dyskursów (literackiego, dziennikarskiego, (auto)biograficznego, historycznego, socjologicznego). Dlatego kształt gatunku wydaje się dziś pochodną struktur typowych dla wielu innych form, w różny sposób i z różnym nasileniem oddziałujących na reportaż w poszczególnych okresach ${ }^{8}$. Efektem tego procesu są przekształcenia widoczne zaróuno w sferze poetologicznej, jak i stricte wydawniczej, objawiające się przyjmowaniem przez gatunek dziennikarski formy książkowej, istotnie uniezależniającej reportaż od prasy drukowanej.

Mariaż obszarów fiction i non-fiction nie jest oczywiście niczym nowym, jeśli weźmiemy pod uwagę chociażby genezę reportażu uprawianego w XIX stuleciu przez wybitnych pisarzy-dziennikarzy, takich jak Henryk Sienkiewicz czy Władysław Stanisław Reymont, dla których korzystanie z technik artystycznych było sposobem na ukształtowanie poetyki reportażowego gatunku. Obecnie - co warto podkreślić możemy zauważyć jednak także ruch odwrotny, który Zygmunt Ziątek przedstawił jako powrót gatunku do suych literackich korzeni ${ }^{9}$. Badacz postawił hipotezę, że

\footnotetext{
${ }^{6}$ E. Szczęsna, Semiospheres, Media, Discourses and Comparative Studies. Some Developmental Perspectives, trans. B. Lutostański, „Tekstualia” 2013, nr 1, s. 50.

${ }^{7}$ Marcin Kołodziejczyk: ta książka..., op. cit., https://wuw.polskieradio24.pl/76/196/Artykul/2083948\%2CMarcin-Kolodziejczyk-ta-ksiazka-w-calosci-sklada-sie-z-podsluchanych-rozmow (dostęp: 16.06.2019).

${ }^{8}$ Badacze uskazują dziś chociażby na takie formy, jak reportaż biograficzny, reportaż poetycki czy reportaż kryminalny.

${ }_{9}$ Por. Z. Ziątek, Dwa dwudziestolecia. Literatura jako reportaż i reportaż jako literatura [w:] Nowe dwudziestolecie (1989-2009). Rozpoznania - hierarchie - perspektywy, red. H. Gosk, Dom Wydawniczy Elipsa, Warszawa 2010.
} 
„dzisiejsze przemieszczanie się do książki (planowanej zuykle jako peuna całość, niezależna od relacji drukowanych w prasie) świadczy, że nie będzie on [reportaż] już tym, czym był dotąd"10.

Śledzeniem i dokumentowaniem wieloaspektowych związków i zależności pomiędzy literaturą a dziennikarstuem zajmował się już Melchior Wańkowicz. W Prosto od krowy pisał, że reportażowi uydzielono „[...] kącik w przedsionku literatury, w którym reportażyści przebywali pod ciągłym strachem eksmisji”" ${ }^{11}$. Dostrzegalna dziś duża popularność non-fiction, jak róunież dynamiczne przekształcenia, jakim ulega sam reportaż, pokazują, że gatunek ten na przestrzeni ostatniego stulecia zdecydowanie uybił się na niezależność i znalazł dla siebie bardzo „komfortowe” miejsce u przestrzeni popkultury. Jednocześnie jednak - niejako w konsekwencji tego procesu - podlegał i nadal podlega rozmaitym formalnym przemianom, otwierając się nie tylko na literackie, ale też pozaliterackie formy wyrazu.

W dobie konwergencji, definiowanej przez Henry'ego Jenkinsa jako „przepłyu treści pomiędzy różnymi platformami medialnymi [..."12, kluczową rolę zaczyna odgrywać odbiorca. Jak zauważa badacz, „konwergencja zachodzi w umysłach pojedynczych konsumentów i poprzez ich społeczne interakcje z innymi konsumentami”"13. Odpowiedzią na te przekształcenia jest tworzenie przekazów atrakcyjnych z punktu widzenia odbiorcy, a jednocześnie łączenie pod uspólną marką kilku zróżnicowanych „produktów”, które dystrybuowane za pośrednictuem wielu kanałów - nie powielają się, lecz skutecznie dopełniają. Proces ten sprzyja tuorzeniu się wokół konkretnej marki (czy byłby nią przykładowo serial, powieść, gra komputerowa, reportaż, czy - szerzej - określony autor $^{14}$ ) społeczności fanowskiej. Fakt ten zasadniczo wpływa na przekształcenia samej marki, która - biorąc pod uwagę już przekazy reporterskie par excellence - ewoluuje w kierunku projektów hybrydycznych: transmedialnych i transgatunkowych, nie tylko komunikujących o rzeczywistości, ale także stanowiących atrakcyjny popkulturowy produkt.

\section{Komparatystyka mediów}

Nakreślone tu wyłącznie szkicowo tendencje i przekształcenia mogą - jak ustępnie zakładam - stać się interesującym materiałem do badań komparatystyki mediów, która włącza w zakres swoich zainteresowań - o czym pisali już między innymi Szczęsna ${ }^{15}$,

\footnotetext{
${ }^{10}$ Ibidem, s. 365.

${ }_{11}$ M. Wańkowicz, Prosto od krowy (o reportażu), „Zeszyty Prasoznawcze” 1961, nr 1-2, s. 93.

${ }^{12}$ H. Jenkins, Kultura konwergencji. Zderzenie starych i nowych mediów, przeł. M. Bernatowicz, M. Filiciak, Wydawnictwa Akademickie i Profesjonalne, Warszawa 2007, s. 9.

${ }^{13}$ Ibidem.

${ }^{14}$ Por. D. Antonik, Autor jako marka, „Teksty Drugie” 2012, nr 6, s. 62-76.

${ }^{15}$ Por. E. Szczęsna, Komparatystyka mediów. Poetyka, semiotyka, komunikacja medialna [w:] Komparatystyka dla humanistów, red. M. Dąbrouski, Wydawnictua Uniuersytetu Warszauskiego, Warszawa 2011.
} 
Adam Regieuicz ${ }^{16}$ i Agnieszka Smaga ${ }^{17}$ - przekazy zarówno „nowych”, jak i „starych” mediów. Regiewicz u tytule jednego ze suych tekstów posłużył się nawet sugestywną eksklamacją: „Na konwergencję - komparatystyka!”" ${ }^{18}$ uskazując tym samym metodę badań porównawczych jako tę najbardziej adekwatną dla badania przekazów trans- oraz intermedialnych. Propozycja ta wpisuje się w paradygmat badań dążących do zastąpienia pojęcia „literatura poróunawcza” szerszą formułą „medióu poróunawczych”, o czym uspomina u swej pracy Andrzej Zawadzki, powołując się na stanowisko Reya Chowa ${ }^{19}$.

Biorąc pod uwagę jej intermedialne oraz interdyscyplinarne nastawienie, niejako programowe otwarcie się na Innego, tendencje do „przekraczania granic” oraz skłonność do tropienia odmienności i analogii pomiędzy zróżnicowanymi dyskursami, komparatystyka wydaje się wartym rozważenia sposobem prowadzenia paralelnych badań nad tekstami literackimi z jednej i przekazami medialnymi z drugiej strony ${ }^{20}$. W zmediatyzowanej rzeczywistości, w której - by powtórzyć za Jacquesem Derridą „nic nie istnieje poza tekstem”, a w uniwersum piśmiennictwa regularnie pojawiają się nowe, hybrydyczne formy, sprawnie łączące media masowe i literaturę (reportaż literacki, powieść reportażowa, twitteratura, powieść na Facebooka etc.), komparatystyka może okazać się swoistym pomostem łączącym oba obszary. Nie można uszak pominąć faktu, że literatura to także medium, choć nastawione głóunie na realizowanie funkcji rozrywkowych czy autotelicznych ${ }^{21}$. Podstawą komunikatów medialnych i dzieł literackich jest przecież piśmienność, która w dobie Web 2.0 ewoluuje nawet u stronę uspomnianej przez Regiewicza „logowizualności”22. W rzeczywistości zmediatyzowanej - jak pisze badacz - „ikonizacja pisma jest sprzężona zurotnie z upiśmiennieniem obrazu”23. Tendencja ta jest zauważalna zaróuno w przestrzeni mediów, jak i literatury, truających w permanentnym poszukiwaniu nowych form wyrazu, będących w stanie najlepiej uchuycić meandry płynnej rzeczywistości.

Badania porównawcze zasadzające się na analizowaniu „upływów oraz źródeł”, które patronowały początkom komparatystyki, a kolejno zostały poddane krytyce

${ }_{16}$ Por. A. Regiewicz, Komparatystyka jako sposób badania nowych mediów, „Teksty Drugie” 2014, nr 2, s. 49-70.

17 Por. A. Smaga, Komparatystyka mediów. Graficzna edycja pisma i obrazu w środowisku cyfrowym - wprowadzenie, „Rocznik Komparatystyczny” 2017, t. 7, s. 91-102.

${ }_{18}$ Por. A. Regiewicz, Na konwergencję - komparatystyka! [w:] Problemy konwergencji mediów, red. M. Kaczmarczyk, D. Rott, Oficyna Wydawnicza „Humanitas”, Sosnowiec-Praga 2013, s. $143-154$.

${ }_{19}$ Por. A. Zawadzki, Między komparatystyka literacką a kulturowa, „Wielogłos” 2010, nr 1-2, s. 50.

${ }^{20}$ Por. A. Kaliszeuski, E. Żyrek-Horodyska, Kilka uwag o metodach analizy tekstów dziennikarskich: ze szczególnym uwzględnieniem reportażu [w:] Metody badań medioznawczych i ich zastosowanie, red. A. Szymańska, M. Lisouska-Magdziarz, A. Hess, Instytut Dziennikarstua, Mediów i Komunikacji Społecznej, Kraków 2018, s. 113-141.

${ }^{21}$ Podkreślić jednak warto, że autoteliczność przekazów cechuje róunież neotelewizję, a u znacznej mierze także postdziennikarstwo en général.

${ }^{22}$ A. Regiewicz, Komparatystyka..., op. cit., s. 54.

${ }^{23}$ Ibidem, s. 53. 
i zastąpione - jak pisze Jonathan Culler - porównaniem uszystkiego ze wszystkim²4, w przypadku komparatystyki mediów nie powinny zostać en bloc zarzucane. Wszak dociekanie wpływów poszczególnych form literackich czy pisarzy na kształtowanie się mediasfery (by przypomnieć tylko zależność reportażu od powieści realistycznej, oddziaływanie twórców oświeceniouych na eseistykę osiemnastowiecznych czasopism moralnych, upływ powieści drukowanej na powieść hipertekstową) to problem wciąż domagający się szerszego omówienia. Wytyczenie linii demarkacyjnej, oddzielającej od siebie literaturę i dziennikarstuo, uniemożliwia w dużej mierze uspólna historia obu tych pól, pozostających ze sobą w licznych strukturalnych i semiotycznych zależnościach. Hołdująca zasadom twórczego remiksu kultura uspółczesna dodatkowo jeszcze komplikuje tę kwestię, uprzywilejouując uykraczające poza uszelkie schematy formy transgatunkowe, będące wynikiem wzajemnego oddziaływania bardzo zróżnicowanych, a często nawet pozornie nieprzystających do siebie, dyskursów.

Zestawianie ze sobą przekazów przynależących do domeny fiction i non-fiction wydaje się zabiegiem w pełni uzasadnionym chociażby przez wzgląd na specyfikę konstrukcji samego poróunania, które - jak pisze Szczęsna - jest peunym uniwersalnym modelem poznawczym ${ }^{25}$. Badaczka podkreśla, że wykorzystanie narzędzi niejako „zarezerwowanych” dla jednej dyscypliny do badania innej może znacząco rozszerzyć pole analiz, gdyż pozuala na wyjście poza praktykowane ucześniej schematy postępowania naukowego. Metodą umożliwiającą tego rodzaju transgresyjne eksploracje są ułaśnie badania porównawcze:

Retoryczność poróunania ujawnia się u tym, że cechy gatunkoue i dyskursywne, wyznaczając miejsca uspólne i różnice zestawianych tekstów, sterują porządkiem interpretacji, decydują o dominantach w procesie rozumienia tekstów ${ }^{26}$.

Kuestią kluczową dla tego rodzaju analiz staje się wskazanie adekwatnego tertium comparationis, pozwalającego znaleźć uzasadnienie dla proponowanego zestawienia. Pomocne $w$ jego odnalezieniu staje się proponowane $u$ tym szkicu zastosowanie metod: close reading (opierającej się na wnikliwej i pogłębionej analizie tekstów fikcjonalnych oraz niefikcjonalnych) oraz distant reading (bazującej na badaniu tematów, idei czy kontekstów). Przykładowo, konfrontowanie ze sobą powieści, reportażu literackiego i reportażu komiksowego - z jakim mamy do czynienia w tym artykule - opiera się, najprościej rzecz ujmując, na założeniu o podobieństwie tematów i wykorzystywanych przez autora środków retorycznych ${ }^{27}$, służących przedstawieniu określonego zagadnienia. Ten sam motyu realizowany poprzez zróżnicowane formy przekazu „pozuala pokazać udział dyskursywności w kreowaniu znaczeń, modelowaniu tematu; pozwala

${ }^{24}$ Por. J. Culler, Porównywalność, przeł. T. Bilczewski [w:] Niewspótmierność. Perspektywy nowoczesnej komparatystyki. Antologia, red. T. Bilczewski, Wydawnictwo Uniwersytetu Jagiellońskiego, Kraków 2010, s. 105.

25 E. Szczęsna, Retoryczność porównania, „Litteraria Copernicana” 2015, nr 2, s. 27-42.

${ }^{26}$ Ibidem, s. 27.

${ }^{27}$ Por. ibidem, s. 34 . 
skonfrontować perspektywy poznawcze"28. Dlatego intermedialne czy transgatunkowe projekty dziennikarskie wydają się materiałem badawczym w sposób naturalny wręcz domagającym się spojrzenia komparatysty.

\section{Cztery debiuty Kołodziejczyka}

Wielość perspektyw, z jakich Kołodziejczyk spogląda na rzeczywistość, prowadzi do konstatacji, że autorowi temu przyszło debiutować kilkakrotnie. W jednym z wywiadów przyznał, że wydanie jego pieruszej książki reportażouej krytycy ogłosili mianem debiutu, choć dziennikarz miał już wówczas za sobą wiele lat pracy w redakcjach prasy drukowanej ${ }^{29}$. „Ciekawiło mnie, co to będzie, jak forma będzie dłuższa” ${ }^{30}$ - podkreślał reporter, sugerując, że u przypadku non-fiction sam sposób przedstawienia faktów ma niewątpliwie istotny upływ na ogólną percepcję wydarzenia. Zatem zmiana nośnika odejście od krótkich, gazetowych tekstów i zurócenie się w kierunku zdecydowanie obszerniejszych, całkowicie niezależnych od rytmu ukazywania się periodyku reportaży książkowych - pozwoliła krytykom określić sytuację, w jakiej znalazł się piszący, mianem jego poutórnego debiutu.

W roku 2016 nastąpił kolejny już „debiut” autora, który we uspółpracy z rysownikiem Marcinem Podolcem stworzył - jak sam podkreśla - pieruszy w Polsce książkouy reportaż komiksouy pt. Morze po kolana. Forma ta - w dobie dominacji kultury audiowizualnej i rosnącego zainteresowania gatunkiem reportażowym - zdaje się nie tylko rozszerzać spektrum przekazów reporterskich, ale także staje się peunym nowym sposobem opowiadania o świecie, praktykowanym z powodzeniem przez takich autorów jak Igort, Aleksander Zograf czy Joe Sacco ${ }^{31}$. Suoistą sylwiczność tej formy trafnie uchuycił Podolec, nazywając ją „narysowanym filmem dokumentalnym”32. Podkreślił przy tym, że największym wyzwaniem, z jakim przyszło mierzyć się autorom już po wydrukowaniu książki, były skrajnie odmienne od zakładanego style jej odbioru. Głóunym problemem okazała się konieczność „odczarowania komiksu”, czyli zburzenia społecznych przekonań, że jest on wyłącznie rysunkową (a zatem niedokumentarną) opowieścią dla dzieci.

Ostatni (jak dotąd) „debiut” Kołodziejczyka przypadł na rok 2018, gdy dziennikarz doszedł do wniosku, że opisywane przez niego „historie przestały się mieścić

\footnotetext{
${ }^{28}$ Ibidem, s. 35.

${ }^{29}$ Marcin Kołodziejczyk: ta książka..., op. cit., https://wuw.polskieradio24.pl/76/196/Artykul/2083948\%2CMarcin-Kolodziejczyk-ta-ksiazka-w-calosci-sklada-sie-z-podsluchanych-rozmow (dostęp: 16.06.2019).

30 Ibidem.

31 Por. K. Lichtblau, Reportaż komiksowy, „Zeszyty Komiksowe” 2015, nr 1, s. 4-9.

${ }^{32}$ Komiks jako literatura faktu, audycja Kultura nie catkiem osobista w Polskim Radiu 24 z dnia 6.11.2016, https://polskieradio24.pl/130/2351/Artykul/1689560 (dostęp: 20.06.2019).
} 
w skromnym formacie [....] reportażu" ${ }^{33}$. Remedium na ograniczenia reportażowej formy okazała się powieść pt. Peryferyjczyk. Jak podkreśla autor, jest ona suoistą kontynuacją jego wcześniejszego dorobku, w którym piszący przyglądał się ludziom zepchniętym na margines społeczny, intelektualnym prowincjuszom. Zapytany o metodę pracy nad tekstem, Kołodziejczyk przyznał, że „to są same podsłuchane rozmouy”" ${ }^{34}$. Przytoczona tu deklaracja każe zastanowić się nad możliwością zawężenia klasyfikacji genologicznej uspomnianego tomu z powieści na powieść reportażową. Forma ta - jak pisze Izabella Adamczeuska - jest przetworzeniem „dokumentu dziennikarskiego, newsa w pouieść” ${ }^{55}$; reportażem „skażonym elementem kreacji” ${ }^{36}$, tekstem charakteryzującym się „elastycznym podejściem do prawdy” ${ }^{37}$. Mozaikowość tekstu, w którym punktem wyjścia są rzeczywiste postaci, prawdziwe rozmowy i często autentyczne uydarzenia, pozwala usytuować go w tekstowo-wizualnym dziennikarskim projekcie Kołodziejczyka, poszukującego wciąż nowych środków wyrazu dla opowiedzenia de facto tej samej historii o ludziach zamieszkujących przestrzeń określaną przez autora jako „planeta prowincja" 38 .

Kolejne omówione tu „debiuty” reportera składają się na wyjątkowo spójny, transgatunkouy projekt dziennikarski, w którym poszczególne tematy i idee (społeczne wykluczenie, codzienność mieszkańców wielkich blokowisk, życie na prowincji) swobodnie przepływają pomiędzy różnymi mediami (powieścią, reportażem, formą komiksową). Podobnie „transgraniczny” wymiar zyskuje wykorzystywany przez dziennikarza język, który z jednej strony ze względu na stosowaną ironię i liczne gry słowne wydaje się daleki od reporterskiej dosłowności, z drugiej - w dobie ponowoczesności paradoksalnie bardzo mocno się do niej zbliża. W każdej z trzech analizowanych tu form uypowiedzi (z których każda posiada charakter synkretyczny) dziennikarz sięga po zbliżony zestaw chwytów: sprawnie operuje gwarą środowiskową, zderza poetyzację z kolokwializacją dyskursu, konfrontuje wysublimowane figury retoryczne z miejskim slangiem. Deformacja rzeczywistości zasadza się tym samym nie tylko na wydarzeniach, lecz także na próbującym je opisać języku, eksponującym karykaturalność kołodziejczykowskiego świata i niewydolność rządzących nim praw.

Postacią spajającą poszczególne elementy reportersko-literackiego projektu jest osoba autora, który przyznaje się do bliskiego powinowactua z bohaterami swoich tekstów. Dziennikarz podkreśla, że przedmiotem jego eksploracji jest środowisko doskonale mu znane, rości sobie więc prawo do zarzucenia chłodnego dystansu na rzecz perspektywy bliskiego obserwatora: „Tak jak Wiech penetruję tylne ulice

\footnotetext{
${ }_{33}$ Marcin Kolodziejczyk: ta książka..., op. cit., https://uwu.polskieradio24.pl/76/196/Artykul/2083948\%2CMarcin-Kolodziejczyk-ta-ksiazka-w-calosci-sklada-sie-z-podsluchanych-rozmow (dostęp: 16.06.2019).

34 Ibidem.

${ }^{35}$ I. Adamczewska, Powieść reportażowa czy dziennikarska? Uwagi o międzywojennej twórczości prozatorskiej Jalu Kurka, „Acta Universitatis Lodziensis” 2015, nr 28, s. 254.

${ }^{36}$ Ibidem.

37 Ibidem.

${ }^{38}$ Por. M. Kołodziejczyk, B. Opowieści z planety prowincja, Wielka Litera, Warszawa 2013.
} 
z rynsztokami i kocimi łbami, bramy i śmietniki. To jestem ja, peryferyjczyk i nie mam z tego powodu kompleksów, by opisywać innych peryferyjczyków"39. W świetle tej deklaracji niektóre fragmenty dziennikarskiego projektu mogą być odczytywane jako sui generis autoreportaże, uwikłane dodatkowo w sieć bardzo mocno eksponowanych językouych nawiązań do prozy Stefana Wiecheckiego.

\section{Reportaż}

Reportaże książkowe Kołodziejczyka istotnie wyróżniają się na gruncie polskiej twórczości non-fiction, a nawet - rzec można - wykraczają poza ramy tradycyjnych gatunków dziennikarskich. Jeśli wziąć pod uwagę najbardziej uproszczoną, klasyczną, słownikową definicję reportażu jako gatunku „obejmującego utwory o charakterze sprawozdań z wydarzeń, których autor był bezpośrednim świadkiem lub uczestnikiem” ${ }^{40}$, z łatwością można zauważyć, jak dalece prace dziennikarskie Kołodziejczyka odchodzą od przywołanych tu wytycznych. Teksty te absorbują elementy powieścioue, felietonowe, eseistyczne; pisane bywają prozą poetycką (np. Wieczór poezji współczesnej pod okiem animatorki kulturalnej ${ }^{41}$ ) lub żargonem z dołączonym obszernym słounikiem podstawowych pojęć (np. Mańki megawypas ${ }^{42}$ ); są nasączone autobiografizacją (np. Śmiech śmiechem, Wiech Wiechem ${ }^{43}$ ) bądź utrzymane w tonie całkowicie odpersonalizowanym, przypominającym akta sprawy tudzież kronikę policyjną (np. Przypadki braci Klusików $\left.{ }^{44}\right)$.

Ze względu na zróżnicowanie formalne poszczególnych reportaży tego autora trudno uskazać zestaw cech koniecznych i wystarczających, które precyzyjnie dookreśliłyby ich poetykę. W przypadku publikacji Kołodziejczyka mamy raczej do czynienia z gatunkiem, który za Zbigniewem Bauerem można by określić jako „antymedialny” ${ }^{45}$. Książki te, będące zazuyczaj zbiorem mikrohistorii, dalekie są bowiem od charakterystycznego dla nowoczesnych środków masowego przekazu dyktatu szybkości i aktualności, upisując się raczej w ideę tzu. slow journalism. Prezentowana opowieść często jest lokalizowana u miejscowości przywoływanej uyłącznie za pomocą pieruszej litery jej nazuy ${ }^{46}$, wydarzenia rozgrywają się w nieoznaczonej bliżej współczesności, bohaterowie

\footnotetext{
${ }_{39}$ Marcin Kołodziejczyk: moim mistrzem jest Wiech, https://wuw.polskieradio24.pl/8/4801/ Artykul/2046356,Marcin-Kolodziejczyk-moim-mistrzem-jest-Wiech (dostęp: 18.06.2019).

${ }^{40}$ Słownik terminów literackich, red. M. Głowiński, J. Sławiński, Open, Warszawa 1998, s. 471.

${ }^{41}$ Por. M. Kołodziejczyk, Wieczór poezji wspótczesnej pod okiem animatorki kulturalnej [w:] Idem, Dysforia. Przypadki mieszczan polskich, Wielka Litera, Warszawa 2015, s. 63-78. ${ }_{42}$ Por. M. Kołodziejczyk, Mańki mega wypas [w:] Idem, Bardzo martwy sezon. Reportaże naoczne, Wielka Litera, Warszawa 2016, s. 85-100.

${ }^{43}$ Por. M. Kołodziejczyk, Śmiech śmiechem, Wiech Wiechem [w:] Idem, Peryferyjczyk. Reportaże z punktu widzenia dumnych niższych sfer, Wielka Litera, Warszawa 2017, s. 11-21.

${ }^{44}$ Por. M. Kołodziejczyk, Przypadki braci Klusików [w:] Idem, Peryferyjczyk..., op. cit., s. 201-210.

${ }^{45}$ Por. Z. Bauer, Antymedialny reportaż Ryszarda Kapuścińskiego, Wydawnictwo PAP, Warszawa 2001.

${ }^{46}$ Na temat przestrzeni u reportażu Kołodziejczyka por. E. Żyrek-Horodyska, Kartografowie codzienności. O przestrzeni (w) reportażu, Instytut Dziennikarstwa, Mediów i Komunikacji
} 
nierzadko są znani uyłącznie z imienia bądź pseudonimu. Przykładem niech będzie chociażby fragment szkicu Gumowy chodzi na tory, w którym czytamy: „Tej nocy Jan G., uulkanizator z miasta M., siedział na nasypie kolejouym i patrzył na przejeżdżające pociągi”" ${ }^{3}$.

Asertoryczność tekstu jest także podważana za pomocą bardzo nielicznych metatekstouych komentarzy autora, który konsekwentnie prezentuje postawę niepoprawnego ironisty, z dystansu spoglądającego zarówno na wykonywany zawód, jak i poszczególne opisywane historie. W reportażu Czy rozmawiał pan już z Modestem? Reportaż w manierze poczytnej gazety ogólnopolskiej dziennikarz - co w jego pracach dość rzadkie - zdradza kulisy swojego warsztatu, demitologizując patetyczny obraz reportera jako tłumacza kultur. Kołodziejczyk tymczasem deklaruje: „W moim przypadku pierusza zasada reporterska sprowadza się do stwierdzenia: zawsze za mało skarpet i majtek"48. Ów zdystansowany ogląd rzeczywistości wydaje się elementem „markującym” dyskurs reportażowy tego autora; jest rodzajem autorskiej sygnatury, zbliżającej reportaże Kołodziejczyka do zdecydowanie szerzej otwierającej się na ironię formy felietonowej.

Elementem spajającym poszczególne mikroopowieści jest interesująca ich twórcę problematyka, ogniskująca się wokół losów uspółczesnych „peryferyjczyków”, mieszkańców „planety prowincja”, tkwiących w marazmie „bardzo martwego sezonu”. W suych tekstach reporter stroni od wielkiej polityki, pomija wydarzenia znane czytelnikowi z pieruszych stron gazet czy serwisów informacyjnych. Unika przywoływania popularnych nazwisk, wielkich historii, zdarzeń o istotnym geopolitycznym zdarzeniu. Bohaterem reportaży Kołodziejczyka jest codzienność, która - jak pokazują prace także wielu innych polskich dziennikarzy - okazuje się obecnie tematem dla reportażu literackiego niezuykle atrakcyjnym, bo prezentowanym najczęściej z uszystkimi możliuymi odcieniami kolorytu lokalnego. Bohaterką tych opowieści staje się najczęściej rzeczyuistość bliska, lecz „egzotyczna”; zuyczajna, ale zaskakująca; często przerysowana, a jednocześnie wpisująca się w doskonale znane czytelnikowi doświadczenia i schematy.

Choć u podtytule jednej z książek dziennikarz deklaruje, że oto zebrane w niej zostały „reportaże naoczne” ${ }^{49}$, większość tekstów nie eksponuje autorskiego „ja”. Piszący bardzo dokładnie opisuje historię, refleksje, plany i działania poszczególnych bohaterów, nie zdradzając przy tym kulis suojego warsztatu (chociażby wiadomości o tym, jak wszedł w posiadanie danej informacji, jak dotarł do bohatera, czego doświadczył w czasie podróży etc.). Narrator-reporter chętnie sięga za to po mowę pozornie zależną, suobodnie łączy własną perspektywę z punktem widzenia bohaterów, upodabniając się przy tym do powieściowego narratora uszechwiedzącego.

Często zdania stanowiące wprowadzenie do poszczególnych reportażouych historii, poprzez ich graficzne wyodrębnienie w przestrzeni tekstu, przypominać mogą lead, który jednak daleki jest od typowej dla form prasowych informacyjnej precyzji.

Społecznej, Kraków 2019, s. 235-260.

${ }_{47}$ M. Kołodziejczyk, B. Opowieści..., op. cit., s. 37.

${ }^{48}$ M. Kołodziejczyk, Dysforia..., op. cit., s. 183.

49 To podtytuł książki Bardzo martwy sezon. 
Warto przytoczyć choć kilka fragmentów otwierających reportaże zebrane w tomie Peryferyjczyk:

Z miłości do rodziny Dorota Z. z Ćmielowa oszukiwała ZUS, Pocztę Polską i śmierć. Ze śmiercią prawie jej się udało ${ }^{50}$.

W Szczecinku samobójca podnosi przed sądem, że życie ocalono mu niestarannie ${ }^{51}$.

Pod koniec października umarł u Gdańsku Wojciech D., który głodował przed magistratem. Był bohaterem z rozpoznawalną twarzą, ale przeszłość dopiero mu tworzono ${ }^{52}$.

O człouieku, który sam się nadał, i co z tego wynikło ${ }^{53}$.

Pod względem konstrukcyjnym wypowiedzi te zbliżają się raczej do opierającej się na suspensie powieści sensacyjnej. Trudno oprzeć się wrażeniu, że w sposobie opowiadania historii autor wyraźnie dąży do parabolizacji, poszukuje efektyunej klamry otwierającej i zamykającej tekst, stosuje syntetyzujące uproszczenia. Codzienność w jego ujęciu nabiera cech niezuykłości i jako taka z powodzeniem może konkurować o uwagę uspółczesnego czytelnika z innymi przekazami kultury popularnej.

\section{Komiks}

Transgatunkowość Morza po kolana wynika przede uszystkim z głóunego założenia projektu, jakim było twórcze zestawienie fragmentów kilku reportaży Kołodziejczyka zamieszczonych pierwotnie w książkach Bardzo martwy sezon oraz B. Opowieści z planety prowincja z „nastrojem Fugazi i Dymu Podolca” ${ }^{4}$. Komiks ten opiera się na połączeniu u spójną opowieść kilku mikrohistorii, opowiadających de facto o bardzo różnych miejscach, zdarzeniach i bohaterach. W swej konstrukcji tom jest zatem zdecydowanie bliższy dopuszczającej tego rodzaju ingerencje faktograficzne powieści reportażowej niż czystemu tekstowi reportażowemu.

W omawianym tu reportażu komiksowym mamy do czynienia z usunięciem autorskiego „ja” z płaszczyzny tekstu. Instancją porządkującą opowieść i niejako wytyczającą jej ramy są rozmowy trzech przyjaciół: Gumowego, Szczurka i Mariana, których losy połączyła wiata autobusowego przystanku. Toczone tam dyskusje odnoszą się zaróuno do (bliżej nieokreślonej) teraźniejszości, jak i na zasadzie reminiscencji przywołują wydarzenia minione, które tłumaczą aktualną sytuację pogrążonych w apatii i bezczynności mężczyzn. Autor-dziennikarz zostaje z tego świata niejako wyłączony. Podobnie jak w książkach reportażowych Kołodziejczyka, czytelnik nie dowiaduje

\footnotetext{
${ }^{50}$ M. Kołodziejczyk, Rodzina we wnętrzu [w:] Idem, Peryferyjczyk..., op. cit., s. 150.

${ }^{51}$ M. Kołodziejczyk, Źle odcięty [u:] Idem, Peryferyjczyk..., op. cit., s. 211.

${ }^{52}$ M. Kołodziejczyk, Święty Harry [w:] Idem, Peryferyjczyk..., op. cit., s. 255.

${ }^{53}$ M. Kołodziejczyk, Zapakowany [w:] Idem, Peryferyjczyk..., op. cit., s. 339.

${ }^{54}$ M. Kołodziejczyk, M. Podolec, op. cit. (informacja ta pojawia się na tylnej okładce tomu).
} 
się, w jaki sposób reporter zdobył informacje, skąd dowiedział się o toczonych na przystanku rozmowach, jak poznał myśli i emocje bohaterów.

Graficzna opowieść rozgrywa się w przestrzeniach doskonale znanych czytelnikowi reportaży Kołodziejczyka: w nadmorskim kurorcie „po sezonie”, na przystanku autobusowym będącym miejscem spotkań lokalnych „peryferyjczyków”, na obszarach oddalonych od kulturowego centrum. Zbliżony do tekstów reportażouych zestaw tematów, jak również analogiczny do ucześniejszych prac Kołodziejczyka język, w formie komiksowej zostają uzupełnione o nowe sensy, generowane za sprawą towarzyszących reportażowemu dyskursowi obrazów. To one właśnie, za pomocą charakterystycznej dla komiksu techniki „zatrzymanego kadru”, eksponują ważne wydarzenia bądź taką właśnie rangę nadają poszczególnym elementom opowieści.

Pomiędzy książkowym reportażem literackim a formą komiksową zachodzi szczególny rodzaj formalnej i percepcyjnej synergii. W przypadku Morza po kolana zastąpienie obszernych, deskryptywnych fragmentów reportażouego tekstu stuorzonymi przez Podolca obrazami pozwoliło zredukować tekst reportera do najciekauszych elementów, wśród których dominują wypowiedzi przypominające sentencje, aforyzmy, bon moty, oparte zazwyczaj na zgrabnym, językouym koncepcie. Warto przywołać kilka z nich: „Niektórzy chcą tu zostać, a inni, dla których nasz przystanek to tylko przystanek, zaraz by uciekli” ${ }^{55}$; „Po sezonie w takim miejscu już tylko się odpoczywa i upiększa stan rzeczywisty”56; „tego dnia przywieźli mózgojeby śliwkowe, w kolorze rubinu. Dzień ucześniej były agrestowe. [...] Życie niesie niespodzianki" ${ }^{\prime 7}$.

Wśród wypowiedzi pojawiają się ponadto takie, w których uwidacznia się zderzenie duóch całkowicie odmiennych rejestrów: potocznego i oficjalnego. Zabieg ten podkreśla groteskowość opisywanych sytuacji, a także (pozornie) indywidualizuje język postaci, będący połączeniem slangu, polszczyzny ogólnopolskiej i stylu urzędowego. Autor czerpie z języka ulicy, wykorzystuje popularne slogany, zakorzenione w popkulturze powiedzenia, jednocześnie je przenicourując, kalecząc, twórczo parafrazując. Warto przytoczyć kilka przykładów: „według niego koleżanka Klaudia miała na jego żonę działanie antykoncepcyjne” ${ }^{2}$; „Gumoury tęsknił do posiadania dzieci” ${ }^{2}$; „Gdy leżał na nogę w szpitalu powiatowym, panowała tam - jak mówi - atmosfera pełna odświętnej zadumy nad zuykłymi sprawami" ${ }^{60}$. Wypowiedzi poszczególnych bohaterów łączą lekkość języka ulicy z patetycznością stylu urzędowego. Jako że u tomie oba te rejestry są ze sobą permanentnie zderzane, warto postawić pytanie o stopień dokumentarności Morza po kolana i rzeczywisty upływ reportera na ukształtowanie języka swoich bohaterów. Wydaje się bowiem, że ów indywidualny, zasadzający się na hiperboli styl

\footnotetext{
${ }^{55}$ Ibidem, s. 9.

${ }^{56}$ Ibidem, s. 25.

57 Ibidem, s. 48.

${ }^{58}$ Ibidem, s. 36.

${ }^{59}$ Ibidem.

${ }^{60}$ Ibidem, s. 31.
} 
jest przede uszystkim elementem markowania dyskursu przez Kołodziejczyka, istotną składową publikacji etykietowanych jako „kołodziejki”.

Faktograficzności komiksowego reportażu nie uwypukla raczej warstwa wizualna książki, która pod wieloma względami oddala się od mimetycznego przedstawienia. Przekaz ikonograficzny jest daleki od realizmu, a poszczególne kadry nierzadko dość luźno korespondują z treścią. Tekstowi Kołodziejczyka towarzyszy grafika, która nie tyle ilustruje tekst, ile wchodzi z nim w swego rodzaju twórczy dialog. Przykładowo, fragmentom opowiadającego o śmierci jednego z bohaterów towarzyszą ilustracje, na których zostaje on przestawiany u postaci anioła ${ }^{61}$, z kolei narracja o uyrzuceniu go z domu przez niedoszłego szwagra została zilustrowana kadrem, na którym mężczyzna (zwany Szczurkiem) został ukazany jako zwierzę (szczur) ${ }^{62}$. Tak ukształtowana w warstuie ikonicznej opowieść poprzez swą ekspresyjność, stosowaną hiperbolę, dosadność wyraźnie koresponduje ze stylem prac Kołodziejczyka. W tym wymiarze obraz niejako podąża za słowem; gry językowe odnajdują swoje odzwierciedlenie u symboliczności obrazu (vide: Szczurek jako mężczyzna i zwierzę). Językowa hiperbola znajduje róunież swoje odbicie w obrazach zasadzających się na zarzuceniu proporcji (vide: obsesja mężczyzny związana z kobiecymi stopami została przedstawiona w formie grafiki prezentującej gigantyczne stopy i maleńkiego, usytuowanego pod jedną z nich mężczyznę $\left.{ }^{63}\right)$.

\section{Powieść}

„Ja często łapię się na tym, że nie mam uystarczającej ilości wyobraźni. Dzielnica jest moja, bohaterowie są ludźmi znanymi mi. Oczywiście mają pozmieniane nazwiska. [...] Niektórzy składają się z kilku innych osób. [....] To uszystko było życie"64 - mówił Kołodziejczyk, prezentując genezę swej powieści pt. Prymityw. Osadzenie opisywanych $\mathrm{w}$ tomie historii $\mathrm{w}$ bardzo konkretnym hic et nunc (drugie dziesięciolecie XXI wieku, prawobrzeżna Warszawa), każe postawić pytanie o możliwość odczytania uspomnianego tu tomu jako powieści reportażowej. Książka ta - zarówno pod uzględem podejmowanych tematów, jak i sposobów obrazowania - pozostaje bowiem w bliskich zależnościach z wcześniejszymi pracami Kołodziejczyka, dając jednocześnie autorowi możliwość nieco odmiennego sposobu oświetlenia kwestii mających kluczowe znaczenie dla całego jego dziennikarskiego projektu.

Już sam podtytuł tomu uyraźnie odwołuje się do klasyfikacji genologicznych, które - choć tak precyzyjnie określone zostały na okładce książki - zostają u niej jednak w rzeczywistości przenicowane. Kołodziejczykouska „epopeja narodowa” nie

\footnotetext{
${ }^{61}$ Por. ibidem, s. 122.

62 Por. ibidem, s. 107.

${ }_{63}$ Por. ibidem, s. 40.

${ }^{64}$ Marcin Kołodziejczyk: ta książka..., op. cit., https://wuw.polskieradio24.pl/76/196/Artykul/2083948\%2CMarcin-Kolodziejczyk-ta-ksiazka-w-calosci-sklada-sie-z-podsluchanych-rozmow (dostęp: 16.06.2019).
} 
mieści się z pewnością u arystotelesouskiej formule „gatunku wysokiego”, zbliżając się raczej do heroicomicum. Zamiast kultu bohaterów odnajdujemy u niej portrety wykluczonych, a podniosły, uroczysty styl zostaje zastąpiony hybrydyczną konstrukcją składającą się ze stylu wysokiego twórczo zremiksowanego z językiem ulicy i mediów. Pouieści nie można z kolei odmówić walorów „narodowych”. Autor z reporterską, a nawet - rzec można - socjologiczną dokładnością śledzi życie wybranych bohaterów i grup społecznych. Jednak zamiast (wzorem romantycznych wieszczów) tworzyć narodowe mity, zajmuje się (po dziennikarsku) sprawnym ich dekonstruowaniem.

Spoiwem reportersko-powieściouego projektu Kołodziejczyka jest niewątpliwie osobliwy styl wypowiedzi. W tonie gawędouym reporter uplata do Prymitywa... frazy fingujące oralność, będące bezpośrednim zwrotem do czytelników („Posłuchajcie [....]"65; „Teraz popatrzcie się na to [.... $]^{60 ”}$; „Zastanawialiście się kiedyś, jak bardzo smutna jest Warszawa z punktu widzenia skuterowego dostawcy pizzy w deszczu?"67). Co istotne, z analogicznym zabiegiem spotykamy się $\mathrm{w}$ jego książkach reporterskich (by przywołać tylko fragment reportażu Dziewczyna z fabryki, w którym czytamy: „Była raz w Małkini taka dzieuczyna, która nie miała zęba jedynki, a drugiej nie miała pół. Nazwisko nic wam nie powie" ${ }^{\prime 6}$ ). W efekcie czytelnik zostaje niejako wciągnięty w konstruowaną opowieść; jego obecność zostaje dostrzeżona i zasygnalizowana przez autora.

W pobieżnym oglądzie tytułowy „prymityw” może wydać się powieściowym odpowiednikiem reportażowego „peryferyjczyka”, zatopionego w szarej codzienności i marzącego o zmianie swej aktualnej sytuacji, lecz niepodejmującego żadnych kroków, by te utopijne plany zrealizować. Sam autor w pełniącym funkcję motta cytacie z Wikipedii podsuwa jednak odbiorcy jeszcze inny trop interpretacyjny:

PRYMITYW (Wikipedia) - rodzaj figur geometrycznych w grafice komputerowej, z których buduje się inne, bardziej skomplikowane. Z punktu widzenia geometrycznej definicji figury, każdą z nich można zbudować z punktów ${ }^{69}$.

Sięgając po taką właśnie „encyklopedyczną” definicję, Kołodziejczyk ucieka niejako od pejoratyunych skojarzeń tytułowego „prymitywa” z barbarzyńcą, człowiekiem grubiańskim i pozbawionym kultury. Poprzez uykorzystanie homonimu (prymityw jako człowiek i jako figura geometryczna) reporter interpretację odbiorcy nakierouruje w całkowicie inną stronę, wskazując na fakt, że tytułowy prymityw jest podstawowym (i niezbywalnym) elementem pewnej większej struktury (technologicznej, ale przecież także i społecznej). Omawianą tu powieść zaludniają ułaśnie tego typu bohaterowie: niespełniony u małżeństwie Jan Kusas, pracownik zakładu pogrzebowego Tatulo Gruco, ambitna mieszkanka Pasymia Wiktoria Wiedeńska. Wspomniane postaci wydają się uręcz przeniesione do powieściowej rzeczywistości z kart reportaży Kołodziejczyka:

\footnotetext{
${ }^{65}$ M. Kołodziejczyk, Prymityw. Epopeja narodowa, Wielka Litera, Warszawa 2018, s. 76.

${ }^{66}$ Ibidem, s. 206.

${ }^{67}$ Ibidem, s. 316.

${ }^{68}$ M. Kołodziejczyk, Dziewczyna z fabryki [w:] Idem, B. Opowieści..., op. cit., s. 7.

${ }^{69}$ M. Kołodziejczyk, Prymityw..., op. cit., s. 7.
} 
posługują się tym samym nasyconym jednocześnie patosem i groteską językiem, borykają z analogicznymi problemami, a dodatkowo żyją w rzeczywistości, która do złudzenia przypomina polskie, prowincjonalne realia.

Możliwość uznania Prymitywa za beletryzowany reportaż pojawia się przede wszystkim w momencie, gdy zwrócimy uwagę na stanowiący tło opowieści wątek społeczno-polityczny, dookreślający czas i miejsce, w jakim żyją bohaterowie. Warto przytoczyć kilka sugestywnych fragmentów:

A gdy się wypełniły dni i zbliżało się lato tego konkretnie 15 roku, w którym młody Bożydar Jałowy pokonał starego Darzbora Memłę, zdobywając tytuł prezydenta Polski - co u sumie nikogo u nas nie obeszło, bo niewielu się orientowało w perspektywach dla kraju, bo sami byliśmy u trudnym położeniu i mieliśmy ciężko $[. . .]^{00}$.

W dobie historycznej lat duutysięcznych-nastych Teść zagorzale sprzyjał partii Radosława Katyńskiego, dlatego że zaistniały u telewizji świat nie odpowiadał mu co do zasady; Teść gardził współczesnością, a współczesność traktowała go viceversa [...] $]^{11}$.

Premier Roland Błysk, widziany w przelocie w dużych pokojach, we wiadomościach, faktycznie jak dywan liniał i się plecami cofał na z góry upatrzone etaty brukselskie ${ }^{72}$.

Trudno oprzeć się wrażeniu, że występujące pod sugestywnymi nazwiskami postaci znane z powieściowej sceny politycznej kumulują $\mathrm{u}$ sobie pewne wyraziste cechy rzeczywiście istniejących polityków. Już sam fakt włączania do opowieści tak rozbudowanego kontekstu politycznego wydaje się dla Kołodziejczyka dość nietypowy i przypomina z peunością zabiegi, jakie stosował chociażby Ryszard Kapuściński na kartach Cesarza. We wcześniejszych reportażouych tomach Kołodziejczyk stronił od tak wyraźnych nawiązań do bieżącej polityki, sytuując losy swoich bohaterów w typowym raczej dla powieści bliżej niedookreślonym czasie. Tymczasem w powieści - co może uydać się zaskakujące - spotykamy się z dość precyzyjnym i charakterystycznym dla dyskursu dziennikarskiego datowaniem (,rok 15”, „lata durutysięczne-naste”, ,późny urzesień '16" "73). Można zatem dostrzec, że powieść otworzyła przed autorem nowe sposoby wyrazu; pozwoliła z większą swobodą odnieść się do aktualnych wydarzeń i rzeczywistych postaci, które w Prymitywie są przedstawiane, co prawda, w kostiumie stworzonym z przerysowanych masek i pseudonimów, z łatwością jednak mogą zostać zdemaskowane.

\footnotetext{
${ }^{70}$ Ibidem, s. 109.

${ }^{71}$ Ibidem, s. 122.

72 Ibidem, s. 207.

${ }^{73}$ Ibidem, s. 9.
} 


\section{Podsumowanie}

Reportaż komiksowy, powieść reporterska, reportaż literacki to trzy wzajemnie warunkujące się i dopełniające (zarówno jeśli chodzi o przepłyu idei, jak i pewnych konceptów lingwistycznych) obszary transgatunkowego projektu Kołodziejczyka. W przestrzeni każdego z nich trudno wytyczyć precyzyjne granice pomiędzy „reporterskością” konkretnego przekazu a jego „literackością”. Ze uzględu na luźne podchodzenie do faktografii (pomijanie nazw miejsc, dat, nazwisk bohaterów) teksty klasyfikowane jako „reportaże” wydają się momentami mało „reporterskie”; z kolei z powodu silnej koncentracji na detalu, szczegółouości, dokumentarności narracji - omóuiona powieść wyraźnie ciąży w stronę dziennikarstwa. Komiks natomiast zdaje się w jednakouym stopniu czerpać z obu tych obszarów, dodatkowo rozszerzając rezerwuar dostępnych autorowi środków wyrazu o elementy wizualne.

Zestawienie ze sobą poszczególnych prac Kołodziejczyka pozwoliło ujaunić kilka uniwersalnych wymiarów transgatunkowego, a jednocześnie niezuykle spójnego projektu, który w dobie kryzysu reprezentacji nie narzuca na rzeczywistość „dokumentarnych”, quasi-obiektywnych ram narracyjnych, lecz opiera się na poszukiwaniu adekwatnych środków wyrazu także $w$ innych, pozadziennikarskich formach komunikowania. Zderzenie ze sobą dyskursu różnych mediów (ich retoryki, poetyki, funkcji i ograniczeń) pokazuje, w jak suobodny sposób określone tematy, style czy idee przemieszczają się między formami dysponującymi nierzadko zgoła odmiennym rezeruuarem środków wyrazu. Choć - jak sugerował w tytule swojej pracy René Etiemble - comparaison n'est pas raison ${ }^{74}$, trudno oprzeć się urażeniu, że to właśnie dynamiczna ewolucja gatunków dziennikarskich i literackich, ich synkretyczność, konwergencja i wzajemne na siebie oddziaływanie (czego doskonałym świadectwem jest omówiona tu twórczość Kołodziejczyka) najdobitniej ujawniają przydatność narzędzi komparatystycznych do badania tekstów funkcjonujących jednocześnie w obu tych obszarach i poddawanych wielokierunkouym oddziaływaniom płynnej nowoczesności.

\section{Bibliografia}

Adamczeuska I., Powieść reportażowa czy dziennikarska? Uwagi o międzywojennej twórczości prozatorskiej Jalu Kurka, „Acta Universitatis Lodziensis” 2015, nr 28, s. 253-272.

Antonik D., Autor jako marka, „Teksty Drugie” 2012, nr 6, s. 62-76.

Bauer Z., Antymedialny reportaż Ryszarda Kapuścińskiego, Wydawnictwo PAP, Warszawa 2001.

Culler J., Porównywalność, przeł. T. Bilczeuski [w:] Niewspótmierność. Perspektywy nowoczesnej komparatystyki. Antologia, red. T. Bilczeuski, Wydaunictwo Uniwersytetu Jagiellońskiego, Kraków 2010.

Etiemble R., Comparaison n'est pas raison. La crise de la littérature comparée, Gallimard, Paris 1963.

${ }^{74}$ Por. R. Etiemble, Comparaison n'est pas raison. La crise de la littérature comparée, Gallimard, Paris 1963. 
Hugo-Bader J., Stare wina i kwasiory. „Peryferyjczyk” Marcina Kołodziejczyka to zapis dorastania $i$ wyrastania, http://wyborcza.pl/duzyformat/7,127290,22623781,stare-wina-i-kwasiory-peryferyjczyk-marcina-kolodziejczyka.html (dostęp: 16.06.2019).

Jenkins H., Kultura konwergencji. Zderzenie starych i nowych mediów, przeł. M. Bernatouicz, M. Filiciak, Wydawnictua Akademickie i Profesjonalne, Warszawa 2007.

Kaliszeuski A., Żyrek-Horodyska E., Kilka uwag o metodach analizy tekstów dziennikarskich: ze szczególnym uwzględnieniem reportażu [w:] Metody badań medioznawczych $i$ ich zastosowanie, red. A. Szymańska, M. Lisouska-Magdziarz, A. Hess, Instytut Dziennikarstua, Mediów i Komunikacji Społecznej, Kraków 2018.

Kołodziejczyk M., B. Opowieści z planety prowincja, Wielka Litera, Warszawa 2013.

Kołodziejczyk M., Bardzo martwy sezon. Reportaże naoczne, Wielka Litera, Warszawa 2016. Kołodziejczyk M., Dysforia. Przypadki mieszczan polskich, Wielka Litera, Warszawa 2015.

Kołodziejczyk M., Peryferyjczyk. Reportaże z punktu widzenia dumnych niższych sfer, Wielka Litera, Warszawa 2017.

Kołodziejczyk M., Prymityw. Epopeja narodowa, Wielka Litera, Warszawa 2018.

Kołodziejczyk M., Podolec M., Morze po kolana, Wielka Litera, Warszawa 2016.

Komiks jako literatura faktu, audycja Kultura nie całkiem osobista w Polskim Radiu 24 z dnia 6.11.2016, https://polskieradio24.pl/130/2351/Artykul/1689560 (dostęp: 20.06.2019).

Lichtblau K., Reportaż komiksowy, „Zeszyty Komiksowe” 2015, nr 1, s. 4-9.

Marcin Kołodziejczyk: ta książka w całości składa się z podstuchanych rozmów, audycja Wybieram Dwójkę z dnia 3.04.2018, https://www.polskieradio24.pl/76/196/ Artykul/2083948\%2CMarcin-Kolodziejczyk-ta-ksiazka-w-calosci-sklada-sie-z-podsluchanych-rozmow (dostęp: 16.06.2019).

Marcin Kołodziejczyk: moim mistrzem jest Wiech, https://wuw.polskieradio24.pl/8/4801/ Artykul/2046356,Marcin-Kolodziejczyk-moim-mistrzem-jest-Wiech (dostęp: 18.06.2019).

Nogaś M., O nowych patriotach polskich, czyli Marcin Kołodziejczyk w Radiu Książki, http:// wyborcza.pl/ksiazki/7,163351,23280061,marcin-kolodziejczyk-u-radiu-ksiazki-opowiada-dlaczego-wkroczyl.html (dostęp: 16.06.2019).

Regiewicz A., Komparatystyka jako sposób badania nowych mediów, „Teksty Drugie” 2014, nr 2, s. 49-70.

Regiewicz A., Na konwergencje - komparatystyka! [w:] Problemy konwergencji mediów, red. M. Kaczmarczyk, D. Rott, Sosnowiec, Oficyna Wydawnicza „Humanitas”, Praga 2013.

Słownik terminów literackich, red. M. Głowiński, J. Sławiński, Open, Warszawa 1998.

Smaga A., Komparatystyka mediów. Graficzna edycja pisma i obrazu w środowisku cyfrowym - wprowadzenie, „Rocznik Komparatystyczny” 2017, t. 7, s. 91-102.

Szczęsna E., Komparatystyka mediów. Poetyka, semiotyka, komunikacja medialna [w:] Komparatystyka dla humanistów, red. M. Dąbrouski, Wydawnictua Uniwersytetu Warszauskiego, Warszawa 2011.

Szczęsna E., Retoryczność porównania, „Litteraria Copernicana” 2015, nr 2, s. 27-42.

Szczęsna E., Semiospheres, Media, Discourses and Comparative Studies. Some Developmental Perspectives, trans. B. Lutostański, „Tekstualia” 2013, nr 1, s. 49-60.

Tatarkiewicz W., Romantyzm, czyli rozpacz semantyka, „Pamiętnik Literacki” 1971, nr 4, s. 3-21.

Wańkowicz M., Prosto od krowy (o reportażu), „Zeszyty Prasoznawcze” 1961, nr 1-2, s. 92-104. Zawadzki A., Między komparatystyką literacka a kulturowa, „Wielogłos” 2010, nr 1-2, s. 39-53. 
Edyta Żyrek-Horodyska

Ziątek Z., Dwa dwudziestolecia. Literatura jako reportaż i reportaż jako literatura [w:] Nowe dwudziestolecie (1989-2009). Rozpoznania - hierarchie - perspektywy, red. H. Gosk, Dom Wydawniczy Elipsa, Warszawa 2010.

Żyrek-Horodyska E., Kartografowie codzienności. O przestrzeni (w) reportażu, Instytut Dziennikarstwa, Mediów i Komunikacji Społecznej Uniwersytetu Jagiellońskiego, Kraków 2019. 